\title{
Epicardial Adipose Tissue and Renal Disease
}

\author{
Narothama Reddy Aeddula ${ }^{1,2, *(\mathbb{D})}$, Wisit Cheungpasitporn ${ }^{3}{ }^{\circledR}$, Charat Thongprayoon ${ }^{4}$ and \\ Samata Pathireddy ${ }^{5}$
}

1 Division of Nephrology, Department of Medicine, Deaconess Health System, 600 Mary street, Evansville, IN 47710, USA

2 Department of Medicine, Indiana University School of Medicine, Evansville, IN 47708, USA

3 Division of Nephrology, Department of Medicine, University of Mississippi Medical Center, Jackson, MS 39216, USA; wcheungpasitporn@gmail.com

4 Division of Nephrology and Hypertension, Department of Medicine, Mayo Clinic, Rochester, MN 55905, USA; charat.thongprayoon@gmail.com

5 Division of Internal Medicine, Department of Medicine, Deaconess Health System, Evansville, IN 47747, USA; drspathireddy@gmail.com

* Correspondence: dr.anreddy@gmail.com or nareddy@iu.edu

Received: 25 January 2019; Accepted: 25 February 2019; Published: 2 March 2019

\begin{abstract}
Epicardial adipose tissue (EAT) is derived from splanchnic mesoderm, localized anatomically between the myocardium and pericardial visceral layer, and surrounds the coronary arteries. Being a metabolically active organ, EAT secretes numerous cytokines, which moderate cardiovascular morphology and function. Through its paracrine and vasocrine secretions, EAT may play a prominent role in modulating cardiac function. EAT protects the heart in normal physiological conditions by secreting a variety of adipokines with anti-atherosclerotic properties, and in contrast, secretes inflammatory molecules in pathologic conditions that may play a dynamic role in the pathogenesis of cardiovascular diseases by promoting atherosclerosis. Considerable research has been focused on comparing the anatomical and biochemical features of EAT in healthy people, and a variety of disease conditions such as cardiovascular diseases and renal diseases. The global cardiovascular morbidity and mortality in renal disease are high, and there is a paucity of concrete evidence and societal guidelines to detect early cardiovascular disease (CVD) in this group of patients. Here we performed a clinical review on the existing evidence and knowledge on EAT in patients with renal disease, to evaluate its application as a reliable, early, noninvasive biomarker and indicator for CVD, and to assess its significance in cardiovascular risk stratification.
\end{abstract}

Keywords: Epicardial Adipose Tissue; Renal disease; Chronic Kidney disease; Inflammation; Coronary artery calcification; Cardiovascular risk

\section{Introduction}

Different fat compartments around the heart (see Figure 1 [1-4]) have different embryological origins and functional activity [5]. Epicardial adipose tissue (EAT), a component of the visceral fat compartment, is located between the myocardium and the pericardial visceral layer, without any separating fascia or other tissue; EAT is directly in contact with the myocardium and coronary vessels [5] (see Figure 1 [1-4]). It covers $80 \%$ of the cardiac surface and accounts for approximately $20 \%$ of the total cardiac weight [6]. EAT is a derivative of splanchnopleuric mesoderm and is comprised of different cell types including adipocytes, nervous and nodal tissue, inflammatory, stromal, and immune cells [7]. 


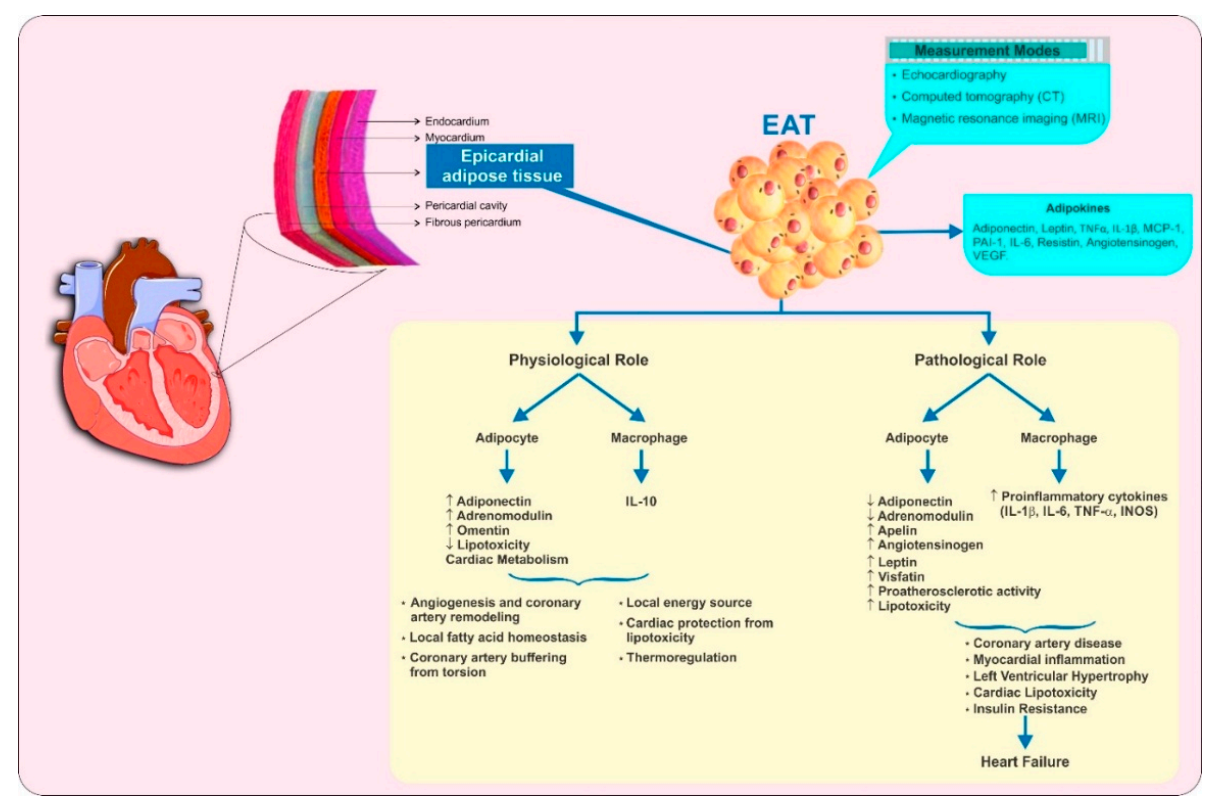

Figure 1. Physiological and pathological functions of epicardial adipose tissue (EAT). Schematic diagram illustrating the anatomical location of EAT, different modalities used to measure it and its various physiological and pathological functions. IL, interleukin; INOS, inducible nitric oxide synthase; MCP-1, monocyte chemoattractant protein-1; PAI-1, plasminogen activator inhibitor-1; TNF- $\alpha$, tumor necrosis factor $\alpha$; VEGF, vascular endothelial growth factor.

Like other white adipose tissues, EAT has an endocrine function with the ability to secrete hormones and inflammatory cytokines [5,7]. Evidence suggests that EAT plays a multifaceted role in essential physiological functions of the heart such as regulation of local fatty acid homeostasis, providing a local energy source, angiogenesis, protecting cardiomyocytes from lipotoxicity by reducing the influx of high free fatty acids, coronary artery remodeling, safeguarding the heart against hypothermia, and buffering of the coronary arteries against torsion induced by myocardial contraction and arterial pulse wave $[4,8,9]$ (see Figure $1[1-4]$ ). Furthermore, the adipocytokines secreted from EAT such as adiponectin, apelin, adrenomedullin, leptin, and omentin have cardioprotective effects [3]. The expression and secretion of proinflammatory cytokines, such as interleukin- 6 (IL-6), interleukin- $1 \beta$ (IL-1 $\beta)$, monocyte chemoattractant protein 1 (MCP-1), and tumor necrosis factor- $\alpha$ (TNF- $\alpha)$, are higher in the EAT of patients with coronary heart disease than in subcutaneous fat of the same individuals, and the pathological enlargement of EAT correlates significantly with increased cardiovascular disease (CVD) risk [10]. The importance of EAT concerning the inflammatory burden in CVD is established [11] with the paracrine and vasocrine secretion of pro-inflammatory adipokines. Adipokines are thought to directly contribute to the myocardial inflammation, left ventricular hypertrophy (LVH), coronary artery disease (CAD), and myocardial dysfunction through the generation of local reactive oxygen species, creating a pro-atherogenic state, and as a direct local effect of inflammatory cytokines [10,12].

Chronic kidney disease (CKD) is one of the leading causes of mortality and morbidity across the globe with its incidence growing exponentially. According to different estimates, CKD has a consistent estimated global prevalence of about 11 to 13\% [13]. As per the World Health Organization's (WHO) global health estimates in 2016, kidney disease was the 12th most common cause of death worldwide, accounting for 1.18 million deaths [14]. CKD is a significant risk factor for CVD and risk increases with increased severity of the CKD. A meta-analysis of the urine albumin-to-creatinine ratio (ACR) data from 105,872 participants and urine protein dipstick measurement data from 1,128,310 participants, found that eGFR (estimated glomerular filtration rate) and albuminuria were associated with all-cause and cardiovascular mortality independently of each other and traditional cardiovascular risk factors [15]. In this study, two-fold higher mortality risk was observed in patients with eGFR $30-45 \mathrm{~mL} / \mathrm{min} / 1.73 \mathrm{~m}^{2}$ as compared to patients with optimal eGFR levels. Similarly, patients with an ACR of approximately 
$100 \mathrm{mg} / \mathrm{g}$ were found to be at two-fold higher risk of mortality as compared to those with optimal ACR levels (5 mg/g) [15].

Considerable evidence indicates a significant association between EAT thickness and the incidence of CVD events in CKD patients. This review summarizes the current knowledge on EAT concerning renal disease, different non-pharmacological and pharmacological modalities to reduce EAT and evaluate it as a reliable, early, new parameter for CVD risk stratification. A literature search was carried out in PubMed and Google Scholar using the various combinations of following keywords: epicardial adipose tissue, chronic kidney disease, end-stage renal disease, renal failure, coronary calcification, and cardiovascular disease. Appropriate articles/abstracts (published in the English language) identified in the search were included in the manuscript.

\section{Pathological Roles of EAT}

Evidence indicates the involvement of cross-talk between EAT and the myocardium in cardiac disease pathogenesis [4]. It is revealed that in patients with essential hypertension and normal LV systolic function, EAT thickness is associated with left ventricular (LV) diastolic dysfunction and increased left atrial volume, independent of blood pressure, LV mass, and other risk factors [16]. In patients with preserved ejection fraction, EAT accumulation might contribute to the initial development of LV systolic dysfunction [17]. Moreover, epicardial fat volume (EFV) is identified as an independent predictor of a rapid increase in lipid-rich plaque volume [18], and acute coronary syndrome in patients with CAD [19].

EAT has been suggested to play a pivotal role in the initiation of atherosclerosis, mediating the secretion of bioactive molecules such as free fatty acids, and a variety of other cytokines or chemokines [1] (see Figure 1 [1-4]). By the expression profile analysis of various inflammatory molecules in EAT and subcutaneous fat isolates from patients undergoing coronary artery bypass grafting (CABG), Mazurek et al. showed significantly higher levels of chemokine MCP-1, and several inflammatory cytokines (IL-1 $\beta$, IL-6, IL-6sR, and TNF- $\alpha$ ) in EAT [7]. Furthermore, secretion of pro-inflammatory cytokines such as TNF- $\alpha$, MCP-1, IL-1 $\beta$, IL-6, and resistin amplified by the size changes in epicardial adipocytes along with the increased number of macrophages and $\mathrm{T}$ lymphocytes ultimately enhance atherogenesis [20,21].

As EAT is in direct contact with the adventitia of coronary arteries, adipocytokines from peri-adventitial EAT may pass through the coronary wall by diffusion and might promote the proliferation of vasa vasorum [22]. Corroborating this, it has been shown in the in vivo studies on pigs that the increase in intimal thickness and coronary artery remodeling could be stimulated by the external application of inflammatory cytokines such as IL-1 $\beta$ and MCP-1 [23,24]. In addition, EAT potentially can influence the coronary arteries through vasocrine secretion by directly releasing adipocytokines and free fatty acids (FFA) $[5,11,22]$. Also, few adipokines such as angiotensinogen, IL-6, MCP-1, TNF- $\alpha$, and visfatin secreted by the EAT could cause inflammation, endothelial and smooth muscle cell proliferation, atherogenesis, and destabilization of atherosclerotic plaque [3]. Adiponectin is a protein hormone that moderates some of the metabolic processes, including glucose regulation and fatty acid oxidation [25]. Adiponectin, which has anti-atherogenic and anti-inflammatory properties, is secreted by EAT in physiological conditions. However, as the EAT becomes hypoxic and dysfunctional in pathologic conditions, adiponectin secretion is affected [26,27]. Notably, the activity of adiponectin and the risk of acute myocardial infarction are inversely associated [28].

Leptin, a hormone predominantly made by the adipose cells, is a mediator of long-term regulation of energy balance, suppressing food intake and thereby inducing weight loss. Leptin secreted by the EAT inhibits nitric oxide synthetase through protein kinase $C$ dependent mechanisms and thereby induce endothelial dysfunction [29]. Adrenomedullin (ADR), a peptide hormone with pleiotropic effects on the vasculature, is significantly associated with EAT in certain disease conditions. Elevated ADR levels are found in CAD patients which are correlated with endothelial dysfunction [30]. Apart from this, vitamin D deficiency has been associated with increased expression of inflammatory 
markers in EAT among animal models [31]. However, it is still unknown if this mechanism applies to humans [32]. Collectively, EAT hypertrophy is observed under various pathological conditions, and the adipocytokines secreted by the infiltrated immune cells in the EAT could potentially induce atherosclerotic cardiac disease.

\section{Measurement of EAT}

Given the widespread availability of non- invasive imaging, EAT measurement has been increasingly performed in the general population, patients with cardiovascular disease, obesity, and diabetes, as it is a reliable predictor of cardiovascular risk, independent of traditional risk factors and other fat depots [5]. Echocardiography, computed tomography (CT), or magnetic resonance imaging (MRI) are the three methods that are used to measure and quantify EAT [5,8]. Various advantages and disadvantages of these three modalities are given in Table 1 [1,33-39]. Echocardiography is a simple, inexpensive, and readily available in health care facilities; however, with high intra- and inter-observer variability, inability to quantify the epicardial fat, and at times overestimation of EAT are some of its significant drawbacks. Precise measurements of EAT could be made with MRI. Despite MRI being a gold standard for EAT measurements, in everyday practice, it is hindered by several drawbacks such as high cost, less availability, and contraindications in patients with pacemakers and implants. Cardiac CT provides better EAT assessment with the highest specificity and sensitivity. An ability to obtain a coronary artery calcification (CAC) score with the cardiac CT improves the cardiovascular risk assessment [26]. Cardiac CT involves only a small radiation dose (1 mSv).

Table 1. Salient features of three different EAT measurement modalities.

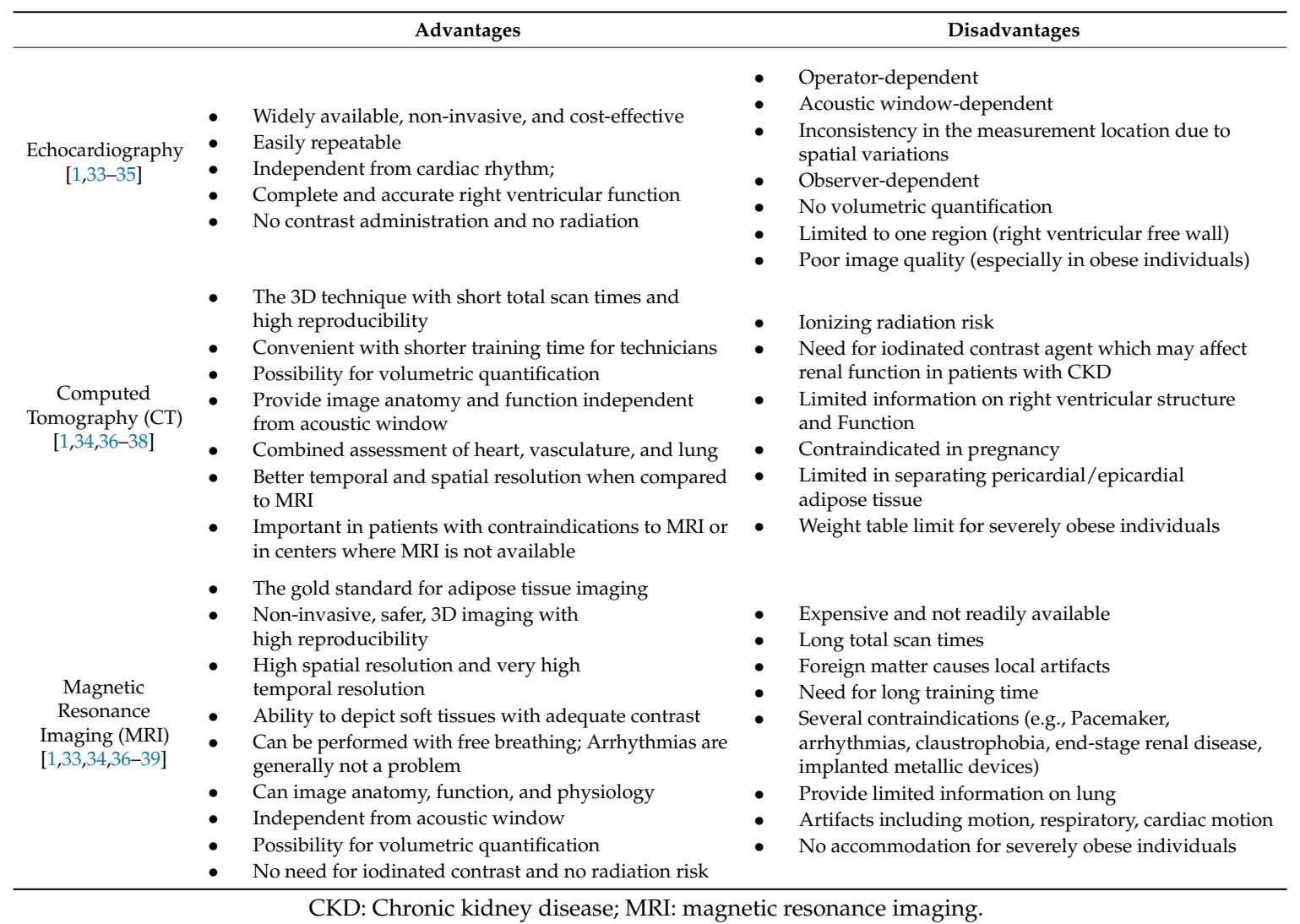

\section{Reference Values of EAT}

Considering the growing body of evidence indicating the profound role of EAT in the pathophysiology of CVD, it is imperative to establish the reference ranges of EAT to differentiate or 
identify the population at risk. Furthermore, to establish EAT as a diagnostic marker, defining the reference ranges becomes a fundamental prerequisite. To this extent, some studies have set forth to evaluate the EAT thickness in different subject groups. Through the histological analysis of 200 human hearts, Schejbal has found the mean EAT thickness of the right ventricle (sharp heart edge close to the bases) as $4.12 \mathrm{~mm}$ [40]. Similar observations were made by Flüchter et al. who estimated the mean right ventricular EAT thickness using cardiac MRI as $4.1 \pm 1.1 \mathrm{~mm}$ in 28 healthy subjects. In the same study, the EAT thickness was found to be less $(3.2 \pm 1.2 \mathrm{~mm})$ in congestive heart failure patients [41].

Of the two analyses carried out on the Framingham Heart MDCT (multi-detector CT) Study participants, Rosito GA et al. determined the EAT thickness as $110 \mathrm{~cm}^{3}$ and $137 \mathrm{~cm}^{3}$ in men and women respectively, and Mahabadi AA et al. estimated the mean EAT volume (of the overall subjects included in the study) as $124 \pm 50 \mathrm{~cm}^{3}$ [42,43]. Furthermore, higher EAT thicknesses were observed in untreated hypertensive patients with grade 1 (impaired relaxation pattern; $7.2 \pm 2.4 \mathrm{~mm}$ ) and grade 2 (pseudo-normal pattern diastolic dysfunction; $7.7 \pm 2.3 \mathrm{~mm}$ ) diastolic dysfunction as compared to subjects with normal diastolic function $(5.4 \pm 1.8 \mathrm{~mm})$ [15]. Demir et al. estimated the EAT thickness of $6.0 \pm 2.0 \mathrm{~mm}$ in patients with metabolic syndrome as compared to $4.0 \pm 1.0 \mathrm{~mm}$ in control group patients $(p<0.001)$ [44]. In a study involving 950 Indian subjects, EFV was significantly higher in patients with non-obstructive CAD $(68.67 \pm 29.18 \mathrm{~mL})$ and obstructive CAD $(82.872 \pm 32.32 \mathrm{~mL})$ as compared to subjects with no CAD $(56.73 \pm 27.63 \mathrm{~mL})(p<0.001)$ [45].

From the existing evidence, it can be considered that EAT thicknesses $>5 \mathrm{~mm}$, or volume $>125 \mathrm{~mL}$, or $68 \mathrm{~mL} / \mathrm{m}^{2}$ as abnormal [35]. However, an extensive review of the literature with a systematic approach corroborated with ample clinical experience of the experts from the field is the need of the hour to establish internationally accepted and reliable reference values for EAT.

\section{EAT in Chronic Kidney Disease (CKD) and End-Stage Renal Disease (ESRD)}

Chronic kidney disease involves chronic inflammation that is exemplified by the presence of increased levels of inflammatory markers such as C-reactive protein (CRP), IL-6, and TNF- $\alpha$ in the circulation [6]. Higher inflammation and oxidative stress are known to play a pivotal role in the development of atherosclerosis in patients with CKD [6]. A growing body of evidence indicates a strong association between increased EAT thickness, inflammatory markers, and CAC in patients with CKD. In a Japanese study on 110 early CKD and 165 non-CKD patients by Nakanishi et al. cardiac CT scan showed significantly increased EAT volume and vulnerable plaque in CKD patients [46].

Several studies have demonstrated that the EAT thickness is high in hemodialysis or peritoneal dialysis patients than the healthy subjects (see Table 2 [47-53]). In a study by Sheng et al. $n 120$ patients with CKD and 30 healthy subjects, cardiac CT showed higher EAT volume in stage 4-5 D CKD group patients compared with the control group; however, EAT volume was similar between CKD 3 and control group [54]. Apart from this, the EFV was significantly higher in the peritoneal dialysis group than in the hemodialysis group, CAD group compared with no CAD group, and in the diabetes group than in no diabetes group. Significant research has been dedicated to understanding the association of EAT thickness in hemodialysis patients with different parameters. In a cross-sectional study on 43 hemodialysis patients and 30 healthy subjects, the neutrophil-to-lymphocyte ratio (a novel inflammatory marker) was found to be an independent predictor of EAT in hemodialysis patients [55]. In another cross-sectional study on 72 hemodialysis patients with ESRD, the activity of paraoxonase-1 (PON-1) enzyme has been shown to be inversely correlated with the EAT thickness [56]. PON-1 is the most potent high-density lipoprotein (HDL) associated antioxidant enzyme whose activity has been demonstrated to be inversely correlated with oxidative stress and cardiovascular risk [56,57]. Apart from this, a strong correlation was observed between EAT thickness and ischemiamodified albumin (IMA) and myeloperoxidase (MPO) in hemodialysis patients; IMA is elevated in ESRD, MPO plays a role in inflammation and CVD [49]. An inverse correlation between EAT thickness and coenzyme Q10 levels was observed in hemodialysis patients as compared to matched healthy subjects in a study by Macunluoglu et al. $(p<0.05)[58]$. 
Table 2. Studies evaluating the EAT thickness in patients on dialysis.

\begin{tabular}{|c|c|c|c|c|c|}
\hline Study & Study Population & Endpoint Concerning EAT & $\begin{array}{l}\text { Mode of EAT } \\
\text { Measurement }\end{array}$ & EAT Thickness & Conclusion \\
\hline \multicolumn{6}{|c|}{ Studies on hemodialysis patients } \\
\hline $\begin{array}{l}\text { Altun et al., } \\
\text { (2014) [47] }\end{array}$ & $\begin{array}{l}62 \text { hemodialysis patients and } \\
40 \text { healthy subjects }\end{array}$ & $\begin{array}{l}\text { Evaluate the relationship } \\
\text { between EAT thickness and } \\
\text { CIMT }\end{array}$ & Echocardiography & $\begin{array}{l}\text { Hemodialysis patients: } \\
6.98 \pm 1.67 \mathrm{~mm} ; \text { Healthy } \\
\text { subjects: } 3.84 \pm 0.73 \mathrm{~mm} ; \\
\quad p<0.001\end{array}$ & $\begin{array}{l}\text { - EAT thickness is higher in hemodialysis patients than in control } \\
\text { subjects and correlated with CIMT, hemodialysis duration, and age. } \\
\text { CIMT, hemodialysis duration and age are independent predictors of } \\
\text { EAT thickness. }\end{array}$ \\
\hline $\begin{array}{l}\text { Aydin et al., } \\
\text { (2017) [48] }\end{array}$ & $\begin{array}{l}60 \text { hemodialysis patients and } \\
84 \text { controls, without diabetes } \\
\text { and CVD; Prospective study }\end{array}$ & Investigate EAT thickness & $\begin{array}{l}\text { Transthoracic } 2 \mathrm{D} \\
\text { echocardiography }\end{array}$ & $\begin{array}{l}\text { Hemodialysis patients: } \\
8.0 \pm 2.2 \mathrm{~mm} ; \text { Healthy subjects: } \\
5.8 \pm 1.9 \mathrm{~mm} ; p<0.01\end{array}$ & $\begin{array}{l}\text { Hemodialysis patients have significantly higher EAT thickness. } \\
\text { Hemodialysis patient status is an independent predictor of } \\
\text { EAT thickness. }\end{array}$ \\
\hline $\begin{array}{l}\text { Karatas et al., } \\
(2018)[49]\end{array}$ & $\begin{array}{l}37 \text { hemodialysis patients, } \\
43 \text { pre-dialysis patients, } \\
31 \text { healthy subjects }\end{array}$ & $\begin{array}{l}\text { Examine the relationship of EAT } \\
\text { thickness with IMA and MPO } \\
\text { levels in patients with CKD }\end{array}$ & $\begin{array}{c}\text { Transthoracic } \\
\text { echocardiography }\end{array}$ & $\begin{array}{c}\text { Hemodialysis patients: } \\
6.841 \pm 1.194 \mathrm{~cm} \text {; pre-dialysis } \\
\text { patients: } 6.261 \pm 1.302 \mathrm{~cm} ; \\
\text { healthy subjects: } \\
4.053 \pm 0.611 \mathrm{~cm} ; p<0.001\end{array}$ & $\begin{array}{l}\text { - EAT is significantly high in the hemodialysis group as compared to } \\
\text { pre-dialysis and healthy subjects. } \\
\text { - IMA and MPO levels are significantly high in hemodialysis subjects. } \\
\text { - EAT thickness positively correlates with IMA and MPO levels }\end{array}$ \\
\hline \multicolumn{6}{|c|}{ Studies on peritoneal dialysis patients } \\
\hline $\begin{array}{l}\text { Turkmen et al., } \\
\text { (2012) [50] }\end{array}$ & $\begin{array}{l}45 \text { Peritoneal dialysis patients, } \\
25 \text { healthy subjects; } \\
\text { Cross-sectional study }\end{array}$ & $\begin{array}{l}\text { Investigate the relationship } \\
\text { between EAT and CAC in } \\
\text { peritoneal dialysis patients }\end{array}$ & MDCT & $\begin{array}{l}\text { Peritoneal dialysis patients: } \\
160 \pm 77 \mathrm{~cm}^{3} ; \text { Healthy subjects: } \\
121.5 \pm 37.5 \mathrm{~cm}^{3} ; p=0.02\end{array}$ & $\begin{array}{l}\text { - EAT thickness is high in peritoneal dialysis patients. } \\
\text { - } \quad \text { AT measurements significantly correlates with arterial calcification } \\
\text { of the main segments of the coronary artery. } \\
\text { - } \quad \text { Patients with BMI } \geq 30 \text { has increased EAT than those with BMI }<30 \\
\text { - Increased EAT positively correlated with age and BMI. }\end{array}$ \\
\hline $\begin{array}{l}\text { Turkmen et al., } \\
\text { (2013) [51] }\end{array}$ & $\begin{array}{l}35 \text { Peritoneal dialysis patients, } \\
30 \text { healthy subjects; } \\
\text { Cross-sectional study }\end{array}$ & $\begin{array}{l}\text { Evaluate PFT thickness and } \\
\text { independent predictors of PFT in } \\
\text { peritoneal dialysis patients }\end{array}$ & MDCT & $\begin{array}{l}\text { Peritoneal dialysis patients: } \\
170 \pm 79 \mathrm{~cm}^{3} ; \text { Healthy subjects: } \\
120 \pm 43 \mathrm{~cm}^{3} ; p=0.003\end{array}$ & - $\quad$ PFT is strongly correlated with EAT in peritoneal dialysis patients. \\
\hline \multicolumn{6}{|c|}{ Studies involving both hemodialysis and peritoneal dialysis patients } \\
\hline $\begin{array}{l}\text { Turkmen et al., } \\
\text { (2011) [52] }\end{array}$ & $\begin{array}{l}80 \text { ESRD patients either on } \\
\text { hemodialysis or peritoneal } \\
\text { dialysis, } 27 \text { healthy subjects; } \\
\text { Cross-sectional study }\end{array}$ & $\begin{array}{l}\text { Investigate the relationship } \\
\text { between EAT and MIAC } \\
\text { syndrome }\end{array}$ & MDCT & $\begin{array}{l}\text { ESRD patients: } 160 \pm 76 \mathrm{~cm}^{3} \\
\text { Healthy subjects: } \\
121.5 \pm 37.5 \mathrm{~cm}^{3} ; p=0.02\end{array}$ & $\begin{array}{l}\text { - Increased EAT in ESRD patients as compared to healthy subjects. } \\
\text { - EAT measurements were higher in peritoneal dialysis patients than } \\
\text { in hemodialysis patients } \\
\text { - EAT significantly correlated with MIAC syndrome in ESRD patients } \\
\text { - EAT significantly increased upon an increase in a number of } \\
\text { MIAC components. } \\
\text { - EAT is positively correlated with age, BMI, and MIAC. }\end{array}$ \\
\hline $\begin{array}{l}\text { Erdur et al., } \\
\text { (2013) [53] }\end{array}$ & $\begin{array}{l}76 \text { ESRD patients receiving } \\
\text { peritoneal- or hemodialysis } \\
\text { and } 42 \text { healthy subjects; } \\
\text { Cross-sectional study }\end{array}$ & $\begin{array}{l}\text { Determine the relationship } \\
\text { between AIP and EAT }\end{array}$ & MDCT & $\begin{array}{l}\text { ESRD patients: } 160 \pm 76 \mathrm{~cm}^{3} \\
\text { Healthy subjects: } 104 \pm 48 \mathrm{~cm}^{3} \\
\qquad p<0.001\end{array}$ & $\begin{array}{l}\text { - Compared to healthy subjects, AIP and EAT are increased in } \\
\text { ESRD patients. } \\
\text { - Significant correlation between EAT and BMI and AIP in } \\
\text { ESRD patients. } \\
\text { - AIP is significantly high in ESRD patients with high EAT volumes. } \\
\text { - Age and BMI are independent predictors of EAT. }\end{array}$ \\
\hline
\end{tabular}

AIP, atherogenic index of plasma; BMI, body mass index; CAC, coronary artery calcification; CIMT, carotid intima-media thickness; CVD, cardiovascular disease; EAT, epicardial adipose tissue; ESRD, end-stage renal disease; IMA, ischemia-modified albumin; MIAC, malnutrition, inflammation, atherosclerosis, calcification; MDCT, multi-detector computed tomography; MPO, myeloperoxidase; PFT, peri-aortic fat tissue. 


\section{EAT in Renal Transplantation}

Limited literature is available on the EAT in kidney transplant patients. In a post hoc analysis on 98 kidney transplant patients, the impact of the epicardial fat gain on ventricular mass after kidney transplantation could not be positively confirmed [59]. Similar to hemodialysis patients, PON-1 activity was found to be inversely correlated with EAT thickness in renal transplant patients [60]. When EAT changes were compared between hemodialysis patients and kidney transplant patients, EAT measurements were significantly higher in hemodialysis patients than in the kidney transplant patients, and the EAT measurements of the kidney transplant patients were not statistically different from the healthy subjects [61]. This suggests that kidney transplantation could reduce EAT as the kidney transplant patients in this study were previously on hemodialysis.

\section{Microalbuminuria and EAT}

Studies demonstrated higher EFV in microalbuminuria patients. In a study on essential hypertensive patients, mean EAT thickness was higher in those with microalbuminuria as compared to the normoalbuminuric patients with significant positive correlations between EAT and LV mass and LV mass index [62]. Akbas et al. made similar observations in type 2 diabetes patients where EAT thickness was significantly high in macro- albuminuric or micro-albuminuric patients than normoalbuminuric patients [63]. Furthermore, EAT was identified as an independent predictor of increased albuminuria in this study. Likewise larger EAT volumes were observed in type 1 diabetes patients with a history of an albumin excretion rate $\geq 300 \mathrm{mg} / \mathrm{dL}$ [64].

\section{EAT and Coronary Artery Calcification in Renal Disease}

Cardiovascular diseases are the most common cause of morbidity and mortality in CKD patients [65]. CAC indicates the presence of coronary atherosclerosis [66], and it usually correlates with increased cardiovascular risk and poor outcomes mainly in patients with CKD [67-70]. EAT measurement is generally used to confirm the association with CAC; it characterizes the presence of high-risk coronary artery plaque $[69,71]$. It is notable that the volume of EAT is eligible as a marker of coronary atherosclerosis even with a coronary artery calcium score of zero on coronary CT angiography [72]. In a large meta-analysis by Nerlekar et al., increased EAT and the presence of high-risk plaque are significantly correlated [73]. In the prospective EVASCAN (EVAluation of CT SCANner) study that investigated the association of EAT thickness with the extent of angiographic CAD, EAT thickness of left ventricle wall was associated with CAD and was identified as an independent predictor of CAD [74]. In the Cardiometabolic risk, Epicardial fat, and Subclinical Atherosclerosis Registry (CAESAR) study participants, increase in EAT and the extent of calcium in the coronary artery are significantly correlated [75]. In a study on the normotensive patients with autosomal dominant polycystic kidney disease (ADPKD), EAT thickness, and carotid intima-media thickness (CIMT) was higher than the control subjects [76], In addition, a statistically significant positive association was observed between EAT thickness and CIMT [76]. A robust association was observed between CAC and EFV in pre-dialysis stage 3-4 CKD patients, and the EFV is greater in individuals with metabolic syndrome, increased insulin resistance, or diabetes mellitus [77]. Through a retrospective analysis on 529 patients with high risk of coronary atherosclerotic nephropathy, Zuo et al. have identified higher EAT thickness in patients with atherosclerosis [78]. The authors suggest that measuring EAT volume could predict the occurrence and development of coronary atherosclerosis in the future [78]. The study also found a positive correlation between EAT volume and coronary artery calcification, BMI and number of coronary lesions in patients with nephropathy [78]. 
When the EAT and CAC score was investigated in diabetic, nondiabetic ESRD patients, and healthy subjects, total CAC scores and EAT measurements were significantly higher in diabetic ESRD patients [79]. A statistically significant relationship was observed between EAT and CAC scores in ESRD patients $(p<0.0001)$ [79]. Furthermore, statistically significant higher EAT measurements were observed in both diabetic and non-diabetic ESRD patients when compared to healthy subjects $(p<0.01$ for healthy subjects vs. ESRD patients). In a study that investigated the relationship between EAT and surrogate cardiovascular markers in patients on maintenance hemodialysis, EFV was significantly higher in patients with higher CAC scores $(>10)$, and it correlated with atherosclerosis, arterial stiffness, and the presence of CAC [80]. However, in a study of 93 patients on long-term hemodialysis, save for the subjects younger than 55 years of age, the EFV was not significantly correlated to the CAC [81]. Taken together, information from most of the studies suggest a strong correlation between EAT thickness and CAC in renal disease patients.

\section{Clinical Significance of EAT in Renal Disease}

In CKD patients, EAT assessment could be a reliable parameter for cardiovascular risk assessment [69]. Inflammation in CKD patients is remarkable when compared to the general population as malnutrition adds onto the already existing high inflammatory state of these patients; as a result, inflammation caused by adipose tissue is more relevant in CKD patients [52,69]. Despite some limitations, the study by Cordeiro et al. provides valuable insights into the association between EAT and CVD risk factors and CV events in CKD patients [82]. In this single-center, cross-sectional, prospective observational study on 227 non-dialyzed stage 3-5 CKD patients, an increase in EAT thickness was associated with severity of CVD; as the EAT thickness increased, the high prevalence of LV hypertrophy and myocardial ischemia was observed along with high CAC score. Furthermore, elevated EAT thickness was associated with poor CVD prognosis. Another important observation from this study is that higher EAT was associated with an increased risk of cardiovascular events independently of visceral (abdominal) fat and other potential confounders [82]. Notably, the authors indicate that EAT does not add any meaningful prognostic power beyond visceral fat and CKD related risk factors. Apart from this, in a 6.1 year follow-up, prospective study on 200 type 2 diabetes patients with elevated urinary albumin excretion rate, EAT was significantly $(p=0.029)$ associated with CVD and mortality even after accounting for traditional CVD risk factors [83]. Moreover, it is suggested that EAT is not a cardiovascular risk indicator in hemodialysis patients without diabetes mellitus and hypertension [84]. However, in a study on 177 outpatients at intermediate risk for CAD, EAT volume was suggested to provide incremental predictive value for future cardiac events [85]. Likewise, in a study by Reinhardt et al., in individuals with early adult onset T2DM, EFV was suggested as a risk factor for heart disease, and in individuals with youth-onset T2DM, it is indicated as a predictor of decreased kidney function [86]. Authors of the study commented that, while EFV might influence renal disease in youth, and renal disease is a precursor to macrovascular disease, it is more likely that EFV is a marker of metabolic syndrome predisposing to both conditions [86]. Metabolic syndrome is linked to epicardial fat storage and EAT might just be a marker of metabolic syndrome or exacerbate the risk of metabolic syndrome on kidney disease [86]. Collectively, it seems that EAT has a prominent role in precipitating CVD events, and these observations deserve thorough examination and consideration in clinical practice, and must be extensively studied further through high-quality clinical studies.

In a post-hoc analysis of a prospective study on 59 hemodialysis patients, EAT correlated significantly with cardiovascular calcification in long-term HD patients [87]. In addition, EAT correlated significantly with age, BMI, CAC, and aortic calcium. In the post-hoc analysis of the Renagel in New Dialysis patients (RIND study) each $10 \mathrm{~cm}^{3}$ increase in EAT volume in hemodialysis patients was associated with a significant $6 \%$ increase in the risk of death during follow-up [88]. Age, BMI, CAC, and aortic calcium were also found to be positively correlated with EAT in the study. In another subgroup analysis of RIND study participants EAT progression from baseline was smaller in hemodialysis patients treated with sevelamer (calcium-free phosphate binder) than in patients 
treated with the calcium-containing phosphate binder [89]. In a study that investigated the relationship between EAT and MIAC (malnutrition, inflammation, atherosclerosis/calcification) syndrome in ESRD patients, total CAC score and EAT measurement were higher, EAT positively correlated with CAC score, age and BMI, and EAT was increased when MIAC components increased [52]. Overall evidence indicates that age, BMI, CIMT, CAC, and hemodialysis status as some of the factors to have a positive correlation with EAT thickness in renal disease patients and hence these factors deem specific consideration during the treatment. As considerable evidence indicates EAT as an independent predictor of CVD and mortality in renal disease patients, it is rational to acknowledge the importance of therapeutic interventions to reduce EAT.

\section{Clinical Reduction of EAT}

Strategies to decrease EAT comprise simple lifestyle modifications including diet control and exercise to medical therapy and even more complex surgical interventions. In a prospective study on 30 non-diabetic obese men with metabolic syndrome, a 3-month weight reduction plan, including diet control and exercise, resulted in a statistically significant $(p<0.001)$ reduction in EAT thickness ranging from $-34 \%$ to $-18 \%$ (as per measurements in various planes) in men who had $>5 \%$ weight loss [90]. Interestingly, the decrement in EAT thickness correlated with improvement in insulin sensitivity index in these subjects. Likewise, in another study on 20 severely obese subjects (BMI $45 \pm 5 \mathrm{~kg} / \mathrm{m}^{2}$ ), a 6 month very low-calorie diet program resulted in 20\% loss of bodyweight, 19\% loss of BMI and importantly $32 \%$ loss of EAT ( $p<0.001)$, as compared to baseline [91]. With weight loss, significant improvements in left ventricular mass (LVM) and diastolic function were also observed in these patients which correlated better with EAT loss rather than BMI or waist circumference reduction.

Concerning medications, statins, and different anti-diabetes medications have been shown to reduce EAT significantly in various studies (see Table 3 for details [92-100]). Independent of the effects on blood cholesterol or lipoproteins, high doses of statins both lower the EAT thickness and its pro-inflammatory characteristics, and thus reduce systemic inflammation [2]. In a study on 193 patients with aortic stenosis undergoing cardiac surgery, statin treatment was associated with significantly lower EAT thickness $(p<0.0001)$ and lower levels of EAT-secreted inflammatory mediators $(p<0.0001)$ [101]. Moreover, the study also identifies a significant correlation between EAT thickness and its inflammatory status.

Different classes of anti-diabetic drugs such as sodium glucose co-transporter-2 inhibitors (SGLT2i), glucagon-like peptide-1 receptor agonist (GLP-1RAs), and dipeptidyl peptidase-4 inhibitors (DPP-4i), have been shown to reduce the EAT thickness to a varying extent; see Table 3 for the details of the observations in various studies. The EAT reduction effect of these anti-diabetic drugs could probably be due to their impact on reducing the body weight or in some cases specifically the body fat. In a study on EAT explants, dapagliflozin, a SGLT2 i have been shown to reduce the secretion of pro-inflammatory chemokines and improve the differentiation of EAT cells [102]. When the expression of pro-inflammatory markers was quantified in EAT of CAD patients with type 2 diabetes who had undergone surgery, pioglitazone, a thiazolidinedione drug, significantly reduced the expression of IL-1 $\beta$, IL-1Ra, and IL-10 [103]. In a study on 73 multi-vessel CAD patients who underwent elective bypass grafting, a combination of simvastatin ( $20 \mathrm{mg} /$ day) and pioglitazone ( $15 \mathrm{mg}$ or $30 \mathrm{mg} /$ day) substantially reduced EAT and plasma inflammatory markers in CAD and metabolic syndrome patients [104]. 
Table 3. Evidence indicating the reduction of EAT with pharmacological intervention.

\begin{tabular}{|c|c|c|c|c|}
\hline Study & Study Population; Study Duration & Pharmacological Therapy and Dose & Results & Conclusion \\
\hline \multicolumn{5}{|c|}{ Statins } \\
\hline $\begin{array}{l}\text { Alexopoulos } \\
\text { et al., (2013) [92] }\end{array}$ & 420 post-menopausal women; One year & $\begin{array}{l}\text { A: Atorvastatin } 80 \mathrm{mg} / \text { day B: } \\
\text { Pravastatin } 40 \mathrm{mg} / \text { day }\end{array}$ & $\begin{array}{l}\text { \% change in EAT. A versus } B^{*}:-3.38(-30.1 \\
\text { to } 40.1) \text { vs. }-0.83 \text { ( }-37.9 \text { to } 62.8) ; p=0.025\end{array}$ & $\begin{array}{l}\text { - Intensive lipid-lowering therapy with atorvastatin significantly } \\
\text { reduces EAT volume. }\end{array}$ \\
\hline $\begin{array}{l}\text { Soucek et al., } \\
(2015)[93]\end{array}$ & $\begin{array}{l}79 \text { patients with } \mathrm{AF} \text { who underwent } \\
\text { pulmonary vein isolation; } 3 \text { months }\end{array}$ & A: Atorvastatin $80 \mathrm{mg} /$ day B: Placebo & $\begin{array}{l}\text { Median decrease in EAT volume (baseline vs. } \\
\text { follow-up) * A: A: } 92.3 \mathrm{~cm}^{3}(62.0 \text { to } 133.3) \text { vs } \\
86.9 \mathrm{~cm}^{3}(64.1 \text { to } 124.8) ; p<0.05 \\
\text { B: } 81.9 \mathrm{~cm}^{3}(55.5 \text { to } 110.9) \text { vs } 81.3 \mathrm{~cm}^{3} \text { (57.1 to } \\
110.5), p=\text { NS. }\end{array}$ & $\begin{array}{l}\text { - Intensive atorvastatin therapy in AF patients who underwent } \\
\text { pulmonary vein isolation significantly decreases EAT thickness. }\end{array}$ \\
\hline \multicolumn{5}{|c|}{ Anti-diabetes medications } \\
\hline \multicolumn{5}{|c|}{ SGLT2i } \\
\hline $\begin{array}{l}\text { Bouchi et al., } \\
\text { (2017) [94] }\end{array}$ & 19 T2D patients; 12 weeks & $\begin{array}{l}\text { Luseogliflozin } 2.5 \mathrm{mg} \text { daily, titrated up } \\
\text { to } 5 \mathrm{mg} \text { daily }\end{array}$ & $\begin{array}{l}\text { Median decrease in EAT volume (baseline vs. } \\
\begin{aligned} \text { follow-up) } & \text { : } 117 \mathrm{~cm}^{3}(96-136) \text { vs. } 111 \mathrm{~cm}^{3} \\
& (88-134) ; p=0.048\end{aligned}\end{array}$ & $\begin{array}{l}\text { - Luseogliflozin significantly reduces EFV in T2D patients. } \\
\text { EFV reduction significantly correlates with C-reactive } \\
\text { protein reduction. }\end{array}$ \\
\hline $\begin{array}{l}\text { Fukuda et al., } \\
\text { (2017) [95] }\end{array}$ & 9 non-obese T2D patients; 12 weeks & Ipragliflozin $50 \mathrm{mg}$ daily & $\begin{array}{l}\text { Median decrease in EAT volume (baseline vs. } \\
\text { follow-up)*: } 102(79-126) \mathrm{cm}^{3} \text { vs. } 89 \\
\qquad(66-109) \mathrm{cm}^{3} ; p=0.008\end{array}$ & $\begin{array}{l}\text { - Ipragliflozin significantly reduces EFV in non-obese } \\
\text { T2D patients. } \\
\text { - EFV reduction significantly correlates with change in BMI. }\end{array}$ \\
\hline $\begin{array}{l}\text { Sato et al., (2018) } \\
{[96]}\end{array}$ & 40 T2D patients with CAD; 6 months & $\begin{array}{l}\text { A: Dapagliflozin B: Conventional } \\
\text { treatment involving various } \\
\text { anti-diabetes drugs }\end{array}$ & $\begin{array}{l}\text { Reduction in EAT volume (A vs. B): } \\
-16.4 \pm 8.3 \mathrm{~cm}^{3} \text { vs. } 4.7 \pm 8.8 \mathrm{~cm}^{3} ; p=0.01\end{array}$ & $\begin{array}{l}\text { - Dapagliflozin reduces EAT volume significantly. } \\
\text { - The significant correlation observed between changes in EAT } \\
\text { volume and the difference in body weight or TNF- } \alpha \text { level. }\end{array}$ \\
\hline $\begin{array}{l}\text { Yagi et al., (2017) } \\
{[97]}\end{array}$ & 13 T2D patients; 6 months & Canagliflozin $100 \mathrm{mg}$ & $\begin{array}{l}\text { The decrease in EAT thickness (baseline vs. } \\
\text { follow-up): } 9.3 \pm 2.5 \mathrm{vs} .7 .3 \pm 2.0 \mathrm{~mm} \\
\qquad p<0.001\end{array}$ & $\begin{array}{l}\text { - Canagliflozin reduces EAT thickness in T2D patients } \\
\text { independent of its effect on blood glucose. }\end{array}$ \\
\hline \multicolumn{5}{|c|}{ GLP-1 Analogues } \\
\hline $\begin{array}{l}\text { Dutour et al., } \\
(2016)[98]\end{array}$ & $\begin{array}{l}44 \text { obese T2D subjects uncontrolled on } \\
\text { oral antidiabetic drugs; } 26 \text { weeks }\end{array}$ & $\begin{array}{l}\text { A: Exenatide } 5 \mu \mathrm{g} \text { to } 10 \mu \mathrm{g} \text { b. i. d. B: } \\
\text { Reference treatment }\end{array}$ & $\begin{array}{l}\text { Reduction in EAT: A: }-8.8 \pm 2.1 \% \\
\text { B: }-1.2 \pm 1.6 \% ; p=0.003\end{array}$ & $\begin{array}{l}\text { - Exenatide significantly reduces EAT in obese T2D patients } \\
\text { - These effects mainly depend on weight loss }\end{array}$ \\
\hline $\begin{array}{l}\text { Iacobellis et al., } \\
\quad(2017) \text { [99] }\end{array}$ & $\begin{array}{l}95 \text { T2D patients with BMI } \geq 27 \mathrm{~kg} / \mathrm{m}^{2} \\
\text { and A1C } \leq 8 \% ; 6 \text { months }\end{array}$ & $\begin{array}{l}\text { A: Liraglutide up to } 1.8 \mathrm{mg} \text { s.c. } \\
\text { o. d. + Metformin up to } 1000 \mathrm{mg} \text { b. i. d. } \\
\text { B: Metformin up to } 1000 \mathrm{mg} \text { b. i. d. }\end{array}$ & $\begin{array}{l}\text { Reduction in EAT (baseline vs. follow-up): } \\
\text { A: } 9.6 \pm 2 \mathrm{~mm} \text { vs. } 6.2 \pm 1.5 \mathrm{~mm} ; p<0.001 \\
\text { B: } 7.4 \pm 1.6 \mathrm{~mm} \text { vs. } 6.9 \pm 1.3 \mathrm{~mm} ; p=\mathrm{NS}\end{array}$ & $\begin{array}{l}\text { - Liraglutide added to metformin results in about } 36 \% \text { reduction } \\
\text { of EAT }\end{array}$ \\
\hline \multicolumn{5}{|c|}{ DPP-4i } \\
\hline $\begin{array}{l}\text { Lima-Martinez } \\
\text { et al., (2106) [100] }\end{array}$ & $\begin{array}{l}26 \text { T2D patients with } \mathrm{A} 1 \mathrm{C} \geq \geq 7 \% \text {; } \\
24 \text { weeks }\end{array}$ & $\begin{array}{l}\text { A: Sitagliptin } 50 \mathrm{mg}+\text { Metformin } \\
\qquad 1000 \mathrm{mg} \text { b. i. d. }\end{array}$ & $\begin{array}{l}\text { Reduction in EAT (baseline vs. follow-up): } \\
\text { A: } 9.98 \pm 2.63 \text { vs. } 8.10 \pm 2.11 \mathrm{~mm} ; p=0.001\end{array}$ & $\begin{array}{l}\text { - Addition of sitagliptin to metformin reduces the EAT } \\
\text { significantly and rapidly }\end{array}$ \\
\hline
\end{tabular}

A1C, glycated hemoglobin; AF, atrial fibrillation; b. i. d., twice daily; BMI, body mass index; DPP-4i, dipeptidyl peptidase-4 inhibitors; EAT, epicardial adipose tissue; EFV, epicardial fat volume; GLP-1RAs, glucagon-like peptide-1 receptor agonists; o. d., once daily; NS, statistically not significant; s. c., sub-cutaneous; SGLT2i, sodium glucose co-transporter-2 inhibitors; T2D, type 2 diabetes mellitus; TNF, tumor necrosis factor; *, values represent median (range). 
Owing to the high sensitivity of renal disease patients to different medications, therapeutic interventions should be carefully chosen to reduce EAT thickness. The 2013 Kidney Disease: Improving Global Outcomes (KDIGO) Clinical Practice Guideline for Lipid Management in Chronic Kidney Disease recommend that statins can be used in adults aged $\geq 50$ years with eGFR $\leq 60 \mathrm{~mL} / \mathrm{min} / 1.73 \mathrm{~m}^{2}$ but not treated with chronic dialysis or kidney transplantation, in adults aged $\geq 50$ years with CKD and eGFR $\geq 60 \mathrm{~mL} / \mathrm{min} / 1.73 \mathrm{~m}^{2}$, in adults aged 18-49 years with CKD, but not treated with chronic dialysis or kidney transplantation, and in adult kidney transplant recipients [105]. In adults with dialysis-dependent $C K D$, the statins are contraindicated; however, statin treatment can be continued if a patient is already receiving statins or statin/ezetimibe combination at the time of dialysis initiation [105]. Special care should be taken while prescribing any of the anti-diabetic drugs in the CKD patients as the American Diabetes Association (ADA) recommends either dose modifications or in some cases contraindicate these drugs [106]. The ADA guidelines do not recommend canagliflozin and dapagliflozin when the eGFR is less than $45 \mathrm{~mL} / \mathrm{min} / 1.73 \mathrm{~m}^{2}$ and $60 \mathrm{~mL} / \mathrm{min} / 1.73 \mathrm{~m}^{2}$ respectively, and contraindicate dapagliflozin in patients with eGFR $<45 \mathrm{~mL} / \mathrm{min} / 1.73 \mathrm{~m}^{2}$ [106]. The 2012 update of the Kidney Disease Outcomes Quality Initiative (KDOQI) Clinical Practice Guideline for Diabetes and Chronic Kidney Disease do not suggest any dosage adjustment for pioglitazone [107]. For sitagliptin, the KDOQI guidelines recommend a dose of $100 \mathrm{mg}$ daily when eGFR $>50 \mathrm{~mL} / \mathrm{min} / 1.73 \mathrm{~m}^{2}, 50 \mathrm{mg}$ daily when eGFR is $30-50 \mathrm{~mL} / \mathrm{min} / 1.73 \mathrm{~m}^{2}$ and $25 \mathrm{mg}$ daily when eGFR $<30 \mathrm{~mL} / \mathrm{min} / 1.73 \mathrm{~m}^{2}$ [107]. Regarding the GLP-1RAs, the KDOQI guidelines do not recommend exenatide and liraglutide when eGFR $<30 \mathrm{~mL} / \mathrm{min} / 1.73 \mathrm{~m}^{2}$ and $<60 \mathrm{~mL} / \mathrm{min} / 1.73 \mathrm{~m}^{2}$ respectively [107].

Surgical interventions involving bariatric surgery or direct surgical resection of EAT have been shown to reduce EAT. In a study on morbidly obese patients, six months after bariatric surgery, epicardial fat volume reduced from $137 \pm 37 \mathrm{~mL}$ to $98 \pm 25 \mathrm{~mL}(p<0.0001)$, along with a substantial reduction in BMI, subcutaneous fat, and visceral abdominal fat [108]. In the case of epicardial hypertrophy, surgical resection has been shown to reduce the EAT and thereby improve cardiac function [109]. Taken together, strategies to reduce EAT thickness should initiate with lifestyle modifications followed with therapeutic intervention. Surgical procedures could be considered as the last option for EAT reduction.

\section{Conclusions}

It has been well established that EAT plays a multifaceted role in cardiac metabolism and its importance in regulating cardiac disease pathogenesis is being accepted widely. Notably, due to its anatomic proximity to the myocardium, EAT is gaining immense attention as inflammatory molecules secreted by EAT could have a paracrine and vasocrine effect on the myocardium. As the EAT thickness could increase before the mature atherosclerotic plaque development, EAT assessment may be useful in screening and initiating treatment during the earlier stages of CVD. Also, EAT could cause coronary artery calcification and may predict its progression, which ultimately results in myocardial ischemia.

Even though CVD poses a significant risk in ESRD patients (mortality rate due to cardiovascular events is high in ESRD patients), they are often asymptomatic due to diabetes or impaired exercise capacity [110]. Traditional screening tools lack predictive accuracy in identifying these symptoms in ESRD patients due to a variety of reasons emanating from their clinical staus [110]. Therefore, there is a quintessential need for identifying risk factor(s) or marker(s) through which future cardiac events could be diagnosed, and the patient could be provided with proper care at the right time. To this extent, we propose that measuring the EAT volume could be a marker for cardiovascular risk stratification in ESRD patients. At this point, we accede that there is a significant dearth of evidence both at the level of animal studies or on humans which strengthen our assumption. However, considerable body of current evidence indicat that CKD and ESRD patients have higher EAT volume motivates to test this hypothesis. Furthermore, to our knowledge, the cause-effect relationship between EAT volume, cardiovascular risk, and renal disease has not been established. Therefore, it also remains a fertile area for future research. 
Also, future large scale trials are required to assess the prognostic significance of reducing the EAT thickness in different patient groups and especially in patients with renal disease. As a positive correlation between EAT thickness and age, BMI, CIMT, CAC and hemodialysis status has been consistently observed in renal disease patients in many independent studies, these factors could be given importance in the clinical practice. Data suggest that EAT thickness can be reduced non-pharmacologically with lifestyle modifications including low-calorie diet and anaerobic exercise. Even though low-quality studies indicate that different pharmacological interventions (mainly statins and some anti-diabetes drugs) can reduce the EAT thickness, high quality randomized, double-blind trials are required to ascertain these effects. Overall, epicardial adipose tissue could be a reliable cardiovascular clinical parameter in both CKD and non-CKD subjects that can be readily measured by non-invasive, cheap and reliable methods to stratify the patients and design the management plan.

Author Contributions: Conceptualization, N.R.A.; formal analysis, N.R.A. and S.P.; investigation, N.R.A.; resources, N.R.A. and S.P.; data curation, N.R.A.; writing-original draft preparation, N.R.A.; writing-review and editing, N.R.A., C.T., W.C., S.P.; visualization, N.R.A.; please turn to the CRediT taxonomy for the term explanation. Authorship must be limited to those who have contributed substantially to the work reported.

Acknowledgments: We would like to acknowledge Syam K. Yelamanchi, for his technical support.

Conflicts of Interest: The authors declare no conflict of interest.

\section{References}

1. Gaborit, B.; Sengenes, C.; Ancel, P.; Jacquier, A.; Dutour-Meyer, A. Role of Epicardial Adipose Tissue in Health and Disease: A Matter of Fat? Compr. Physiol. 2017, 7, 1051-1082. [CrossRef] [PubMed]

2. Packer, M. Epicardial adipose tissue may mediate deleterious effects of obesity and inflammation on the myocardium. J. Am. Coll. Cardiol. 2018, 71, 2360-2372. [CrossRef] [PubMed]

3. Patel, V.B.; Shah, S.; Verma, S.; Oudit, G.Y. Epicardial adipose tissue as a metabolic transducer: Role in heart failure and coronary artery disease. Heart Fail. Rev. 2017, 22, 889-902. [CrossRef] [PubMed]

4. Antonopoulos, A.S.; Antoniades, C. The role of epicardial adipose tissue in cardiac biology: Classic concepts and emerging roles. J. Physiol. 2017, 595, 3907-3917. [CrossRef] [PubMed]

5. Nagy, E.; Jermendy, A.L.; Merkely, B.; Maurovich-Horvat, P. Clinical importance of epicardial adipose tissue. Arch. Med. Sci. 2017, 13, 864-874. [CrossRef] [PubMed]

6. Graham-Brown, M.P.M.; McCann, G.P.; Burton, J.O. Epicardial adipose tissue in patients with endstage renal disease on haemodialysis. Curr. Opin. Nephrol. Hypertens. 2015, 24, 517-524. [CrossRef] [PubMed]

7. Mazurek, T.; Zhang, L.; Zalewski, A.; Mannion, J.D.; Diehl, J.T.; Arafat, H.; Lea Sarov-Blat, L.; O’Brien, S.; Keiper, E.A.; Johnson, A.G.; et al. Human epicardial adipose tissue is a source of inflammatory mediators. Circulation 2003, 108, 2460-2466. [CrossRef] [PubMed]

8. Sacks, H.S.; Fain, J.N. Human epicardial fat: What is new and what is missing? Clin. Exp. Pharmacol. Physiol. 2011, 38, 879-887. [CrossRef] [PubMed]

9. Wronska, A.; Kmiec, Z. Structural and biochemical characteristics of various white adipose tissue depots. Acta Physiol. 2012, 205, 194-208. [CrossRef] [PubMed]

10. Guzzardi, M.A.; Iozzo, P. Fatty heart, cardiac damage, and inflammation. Rev. Diabet. Stud. 2011, 8, 403-417. [CrossRef] [PubMed]

11. Iacobellis, G.; Gao, Y.J.; Sharma, A.M. Do cardiac and perivascular adipose tissue play a role in atherosclerosis? Curr. Diabetes Rep. 2008, 8, 20-24. [CrossRef]

12. Baker, A.R.; Da Silva, N.F.; Quinn, D.W.; Harte, A.L.; Pagano, D.; Bonser, R.S.; Kumar, S.; McTernan, P.G. Human epicardial adipose tissue expresses a pathogenic profile of adipocytokines in patients with cardiovascular disease. Cardiovasc. Diabetol. 2006, 5, 1. [CrossRef] [PubMed]

13. Hill, N.R.; Fatoba, S.T.; Oke, J.L.; Hirst, J.A.; O'Callaghan, C.A.; Lasserson, D.S.; Hobbs, F.R. Global prevalence of chronic kidney disease-A systematic review and meta-analysis. PLoS ONE 2016, 11, e0158765. [CrossRef] [PubMed]

14. World Health Organization (WHO). Global Health Estimates 2016. Available online: https:/ /www.who.int/ healthinfo/global_burden_disease/estimates/en/ (accessed on 14 December 2018). 
15. Chronic Kidney Disease Prognosis Consortium. Association of estimated glomerular filtration rate and albuminuria with all-cause and cardiovascular mortality in general population cohorts: A collaborative meta-analysis. Lancet 2010, 375, 2073-2081. [CrossRef]

16. Çetin, M.; Kocaman, S.A.; Durakoğlugil, M.E.; Erdoğan, T.; Ergül, E.; Dogan, S.; Çanga, A. Effect of epicardial adipose tissue on diastolic functions and left atrial dimension in untreated hypertensive patients with normal systolic function. J. Cardiol. 2013, 61, 359-364. [CrossRef] [PubMed]

17. Watanabe, K.; Kishino, T.; Sano, J.; Ariga, T.; Okuyama, S.; Mori, H.; Matsushima, S.; Ohtsuka, K.; Ohnishi, H.; Watanabe, T. Relationship between epicardial adipose tissue thickness and early impairment of left ventricular systolic function in patients with preserved ejection fraction. Heart Vessels 2016, 31, 1010-1015. [CrossRef] [PubMed]

18. You, S.; Sun, J.S.; Park, S.Y.; Baek, Y.; Kang, D.K. Relationship between indexed epicardial fat volume and coronary plaque volume assessed by cardiac multidetector CT. Medicine 2016, 95, e4164. [CrossRef] [PubMed]

19. Ito, T.; Nasu, K.; Terashima, M.; Ehara, M.; Kinoshita, Y.; Ito, T.; Kimura, M.; Tanaka, N.; Habara, M.; Tsuchikane, E.; et al. The impact of epicardial fat volume on coronary plaque vulnerability: Insight from optical coherence tomography analysis. Eur. Heart J. Cardiovasc. Imaging 2012, 13, 408-415. [CrossRef] [PubMed]

20. Karastergiou, K.; Evans, I.; Ogston, N.; Miheisi, N.; Nair, D.; Kaski, J.C.; Marjan Jahangiri, M.; Mohamed-Ali, V. Epicardial adipokines in obesity and coronary artery disease induce atherogenic changes in monocytes and endothelial cells. Arterioscler. Thromb. Vasc. Biol. 2010, 30, 1340-1346. [CrossRef] [PubMed]

21. Rampino, T.; Gregorini, M.; Bedino, G.; Piotti, G.; Gabanti, E.; Ibatici, A.; Sessarego, N.; Piacenza, C.; Balenzano, C.T.; Esposito, P.; et al. Mesenchymal stromal cells improve renal injury in anti-Thy 1 nephritis by modulating inflammatory cytokines and scatter factors. Clin. Sci. 2011, 120, 25-36. [CrossRef] [PubMed]

22. Raggi, P. Epicardial adipose tissue and progression of coronary artery calcium: Cause and effect or simple association? JACC Cardiovasc. Imaging 2014, 7, 917-919. [CrossRef] [PubMed]

23. Shimokawa, H.; Ito, A.; Fukumoto, Y.; Kadokami, T.; Nakaike, R.; Sakata, M.; Takayanagi, T.; Egashira, K.; Takeshita, A. Chronic treatment with interleukin-1 beta induces coronary intimal lesions and vasospastic responses in pigs in vivo. The role of platelet-derived growth factor. J. Clin. Investig. 1996, 97, 769-776. [CrossRef] [PubMed]

24. Miyata, K.; Shimokawa, H.; Kandabashi, T.; Higo, T.; Morishige, K.; Eto, Y.; Takeshita, A. Rho-kinase is involved in macrophage-mediated formation of coronary vascular lesions in pigs in vivo. Arterioscler. Thromb. Vasc. Biol. 2000, 20, 2351-2358. [CrossRef] [PubMed]

25. Díez, J.J.; Iglesias, P. The role of the novel adipocyte-derived hormone adiponectin in human disease. Eur. J. Endocrinol. 2003, 148, 293-300. [CrossRef] [PubMed]

26. Greenstein, A.S.; Khavandi, K.; Withers, S.B.; Sonoyama, K.; Clancy, O.; Jeziorska, M.; Laing, I.; Yates, A.P.; Pemberton, P.W.; Malik, R.A.; et al. Local inflammation and hypoxia abolish the protective anticontractile properties of perivascular fat in obese patients. Circulation 2009, 119, 1661-1670. [CrossRef] [PubMed]

27. Pang, C.; Gao, Z.; Yin, J.; Zhang, J.; Jia, W.; Ye, J. Macrophage infiltration into adipose tissue may promote angiogenesis for adipose tissue remodeling in obesity. Am. J. Physiol. Endocrinol. Metab. 2008, 295, E313-E322. [CrossRef] [PubMed]

28. Pischon, T.; Girman, C.J.; Hotamisligil, G.S.; Rifai, N.; Hu, F.B.; Rimm, E.B. Plasma adiponectin levels and risk of myocardial infarction in men. JAMA 2004, 291, 1730-1737. [CrossRef] [PubMed]

29. Payne, G.A.; Bohlen, H.G.; Dincer, U.D.; Borbouse, L.; Tune, J.D. Periadventitial adipose tissue impairs coronary endothelial function via PKC-beta-dependent phosphorylation of nitric oxide synthase. Am. J. Physiol. Heart Circ. Physiol. 2009, 297, H460-H465. [CrossRef] [PubMed]

30. Silaghi, A.; Achard, V.; Paulmyer-Lacroix, O.; Scridon, T.; Tassistro, V.; Duncea, I.; Clément, K.; Dutour, A.; Grino, M. Expression of adrenomedullin in human epicardial adipose tissue: Role of coronary status. Am. J. Physiol. Endocrinol. Metab. 2007, 293, E1443-E1450. [CrossRef] [PubMed]

31. Gupta, G.K.; Agrawal, T.; DelCore, M.G.; Mohiuddin, S.M.; Agrawal, D.K. Vitamin D deficiency induces cardiac hypertrophy and inflammation in epicardial adipose tissue in hypercholesterolemic swine. Exp. Mol. Pathol. 2012, 93, 82-90. [CrossRef] [PubMed]

32. Utku, I.K.; Okuturlar, Y.; Demir, E.; Harmankaya, O.; Aciksari, G.; Uygun, T.; Kumbasar, A. Relationship between epicardial adipose tissue thickness and vitamin $\mathrm{D}$ in patients with metabolic syndrome. Int. J. Clin. Exp. Med. 2015, 8, 5707-5714. 
33. Peluso, D.; Tona, F.; Muraru, D.; Romeo, G.; Cucchini, U.; Marra, M.P.; Iliceto, S.; Badano, L.P. Right ventricular geometry and function in pulmonary hypertension: Non-invasive evaluation. Diseases 2014, 2, 274-295. [CrossRef]

34. Baessler, B.; Schmidt, M.; Lücke, C.; Blazek, S.; Ou, P.; Maintz, D.; Bunck, A.C. Modern imaging of myocarditis: Possibilities and challenges. Fortschr Röntgenstr 2016, 188, 915-925. [CrossRef]

35. Bertaso, A.G.; Bertol, D.; Duncan, B.B.; Foppa, M. Epicardial fat: Definition, measurements and systematic review of main outcomes. Arquivos Brasileiros de Cardiologia 2013, 101, e18-e28. [CrossRef] [PubMed]

36. Atalay, M.K. Cardiothoracic Imaging a report by Cardiac Magnetic Resonance Imaging and Computed Tomography-State of the Art. 2019. Available online: https://www.researchgate.net/ publication/267825158_Cardiothoracic_Imaging_a_report_by_Cardiac_Magnetic_Resonance_Imaging_ and_Computed_Tomography-_State_of_the_Art (accessed on 8 January 2019).

37. Dellegrottaglie, S.; Ostenfeld, E.; Sanz, J.; Scatteia, A.; Perrone-Filardi, P.; Bossone, E. Imaging the Right Heart-Pulmonary Circulation Unit: The Role of MRI and Computed Tomography. Heart Fail. Clin. 2018, 14, 377-391. [CrossRef] [PubMed]

38. Kwong, R.Y.; Yucel, E.K. Computed tomography scan and magnetic resonance imaging. Circulation 2003, 108, e104-e106. [CrossRef] [PubMed]

39. Lima, J.A.; Desai, M.Y. Cardiovascular magnetic resonance imaging: Current and emerging applications. J. Am. Coll. Cardiol. 2004, 44, 1164-1171. [CrossRef] [PubMed]

40. Schejbal, V. Epicardial fatty tissue of the right ventricle-morphology, morphometry and functional significance. Pneumologie 1989, 43, 490-499. [PubMed]

41. Flüchter, S.; Haghi, D.; Dinter, D.; Heberlein, W.; Kühl, H.P.; Neff, W.; Papavassiliu, T. Volumetric assessment of epicardial adipose tissue with cardiovascular magnetic resonance imaging. Obesity 2007, 15, 870-878. [CrossRef] [PubMed]

42. Rosito, G.A.; Massaro, J.M.; Hoffmann, U.; Ruberg, F.L.; Mahabadi, A.A.; Vasan, R.S.; O'Donnell, J.M.; Fox, C.S. Pericardial fat, visceral abdominal fat, cardiovascular disease risk factors, and vascular calcification in a community-based sample: The Framingham Heart Study. Circulation 2008, 117, 605-613. [CrossRef] [PubMed]

43. Mahabadi, A.A.; Massaro, J.M.; Rosito, G.A.; Levy, D.; Murabito, J.M.; Wolf, P.A.; O'Donnell, J.M.; Fox, C.S. Association of pericardial fat, intrathoracic fat, and visceral abdominal fat with cardiovascular disease burden: The Framingham Heart Study. Eur. Heart J. 2009, 30, 850-856. [CrossRef] [PubMed]

44. Demir, B.; Demir, E.; Acıksarı, G.; Uygun, T.; Utku, I.K.; Gedikbasi, A.; Caglar, I.M.; Pirhan, O.; Tureli, H.O.; Oflar, E.; et al. The association between the epicardial adipose tissue thickness and oxidative stress parameters in isolated metabolic syndrome patients: A multimarker approach. Int. J. Endocrinol. 2014, 2014, 954045. [CrossRef] [PubMed]

45. Khurana, R.; Yadav, A.; Buxi, T.B.; Sawhney, J.P.; Rawat, K.S.; Ghuman, S.S. Correlation of epicardial fat quantification with severity of coronary artery disease: A study in Indian population. Indian Heart J. 2018, 70 (Suppl. 3), S140-S145. [CrossRef] [PubMed]

46. Nakanishi, K.; Fukuda, S.; Tanaka, A.; Otsuka, K.; Taguchi, H.; Yoshikawa, J.; Shimada, K. Epicardial adipose tissue accumulation is associated with renal dysfunction and coronary plaque morphology on multidetector computed tomography. Circ. J. 2016, 80, 196-201. [CrossRef] [PubMed]

47. Altun, B.; Tasolar, H.; Eren, N.; Binnetoğlu, E.; Altun, M.; Temiz, A.; Gazi, E.; Barutcu, A.; Altunören, O.; Çölkesen, Y. Epicardial adipose tissue thickness in hemodialysis patients. Echocardiography 2014, 31, 941-946. [CrossRef] [PubMed]

48. Aydın, E.; Altın, C.; Sakallığlu, O.; Yılmaz, M.; Gezmiş, E.; Sade, L.E.; Müderrisoğlu, H. Epicardial adipose tissue thickness and carotid intima-media thickness in hemodialysis patients. Acta Cardiol. Sin. 2017, 33, 266-272. [PubMed]

49. Karatas, A.; Canakci, E.; Bektas, O.; Bayrak, T.; Bayrak, A.; Altınbas, A.; Turkmen, E. Relationship of epicardial fat tissue thickness with oxidant biomarkers in chronic kidney disease. Bratisl. Lek. Listy 2018, 119, 566-571. [CrossRef] [PubMed]

50. Turkmen, K.; Ozbek, O.; Kayikcioğlu, H.; Kayrak, M.; Solak, Y.; Nayman, A.; Anil, M.; Babur, H.; Tonbul, H.Z. The relationship between epicardial adipose tissue and coronary artery calcification in peritoneal dialysis patients. Cardiorenal Med. 2012, 2, 43-51. [CrossRef] [PubMed] 
51. Turkmen, K.; Ozbek, O.; Kayrak, M.; Samur, C.; Guler, I.; Tonbul, H.Z. Peri-aortic fat tissue thickness in peritoneal dialysis patients. Perit. Dial. Int. 2013, 33, 316-324. [CrossRef] [PubMed]

52. Turkmen, K.; Kayikcioglu, H.; Ozbek, O.; Solak, Y.; Kayrak, M.; Samur, C.; Anil, M.; Tonbul, H.Z. The relationship between epicardial adipose tissue and malnutrition, inflammation, atherosclerosis/calcification syndrome in ESRD patients. Clin. J. Am. Soc. Nephrol. 2011, 6, 1920-1925. [CrossRef] [PubMed]

53. Erdur, M.F.; Tonbul, H.Z.; Ozbiner, H.; Ozcicek, A.; Ozcicek, F.; Akbas, E.M.; Ozbek, O.; Hamur, H.; Turkmen, K. The relationship between the atherogenic index of plasma and epicardial adipose tissue in hemodialysis and peritoneal dialysis patients. Ren. Fail. 2013, 35, 1193-1198. [CrossRef] [PubMed]

54. Sheng, Y.N.; Zhao, D.M.; Ma, Q.L.; Gao, Y. Association between epicardial fat volume and coronary artery calcification in patients with chronic kidney disease. Zhonghua Xin Xue Guan Bing Za Zhi 2017, 45, 121-125. [PubMed]

55. Ozcicek, A.; Ozcicek, F.; Yildiz, G.; Timuroglu, A.; Demirtas, L.; Buyuklu, M.; Kuyrukluyildiz, U.; Akbas, E.M.; Topal, E.; Turkmen, K. Neutrophil-to-lymphocyte ratio as a possible indicator of epicardial adipose tissue in patients undergoing hemodialysis. Archives of medical science. Arch. Med. Sci. 2017, 13, 118-123. [CrossRef] [PubMed]

56. Abdallah, E.; El-Shishtawy, S.; Sherif, N.; Ali, A.; El-Bendary, O. Assessment of the relationship between serum paraoxonase activity and epicardial adipose tissue in hemodialysis patients. Int. Urol. Nephrol. 2017, 49, 329-335. [CrossRef] [PubMed]

57. Bełtowski, J.; Wójcicka, G.; Jamroz, A. Leptin decreases plasma paraoxonase 1 (PON1) activity and induces oxidative stress: The possible novel mechanism for proatherogenic effect of chronic hyperleptinemia. Atherosclerosis 2003, 170, 21-29. [CrossRef]

58. Macunluoglu, B.; Atakan, A.; Ari, E.; Kaya, Y.; Kaspar, C.; Demir, H.; Alp, H.H. Epicardial fat tissue thickness is correlated with diminished levels of co-enzyme Q10, a major antioxidant molecule among hemodialysis patients. Clin. Biochem. 2014, 47, 1231-1234. [CrossRef] [PubMed]

59. Yazbek, D.C.; Carvalho, A.B.; Barros, C.S.; Pestana, J.O.; Rochitte, C.E.; dos Santos Filho, R.D.; Canziani, M.E.F. Is there relationship between epicardial fat and cardiovascular parameters in incident kidney transplant patients? A post-hoc analysis. PLoS ONE 2018, 13, e0191009. [CrossRef] [PubMed]

60. Eroglu, E.; Kocyigit, I.; Unal, A.; Korkar, H.; Karakukcu, C.; Orscelik, O.; Sipahioglu, M.H.; Tokgoz, B.; Oymak, O. Serum paraoxonase activity is associated with epicardial fat tissue in renal transplant recipients. Int. Urol. Nephrol. 2015, 47, 1409-1414. [CrossRef] [PubMed]

61. Çolak, H.; Kilicarslan, B.; Tekce, H.; Tanrisev, M.; Tugmen, C.; Aktas, G.; Kursat, S. Relationship between epicardial adipose tissue, inflammation and volume markers in hemodialysis and transplant patients. Ther. Apher. Dial. 2015, 19, 56-62. [CrossRef] [PubMed]

62. Ozturk, M.T.; Ebinç, F.A.; Okyay, G.U.; Kutlugün, A.A. Epicardial adiposity is associated with microalbuminuria in patients with essential hypertension. Acta Cardiol. Sin. 2017, 33, 74-80. [CrossRef] [PubMed]

63. Akbas, E.M.; Demirtas, L.; Ozcicek, A.; Timuroglu, A.; Bakirci, E.M.; Hamur, H.; Ozcicek, F.; Turkmen, K. Association of epicardial adipose tissue, neutrophil-to-lymphocyte ratio and platelet-to-lymphocyte ratio with diabetic nephropathy. Int. J. Clin. Exp. Med. 2014, 7, 1794-1801. [PubMed]

64. Darabian, S.; Backlund, J.Y.; Cleary, P.A.; Sheidaee, N.; Bebu, I.; Lachin, J.M.; Budoff, M.J.; DCCT /EDIC Research Group. Significance of epicardial and intrathoracic adipose tissue volume among type 1 diabetes patients in the DCCT/EDIC: A pilot study. PLOS ONE 2016, 11, e0159958. [CrossRef] [PubMed]

65. Afsar, B.; Turkmen, K.; Covic, A.; Kanbay, M. An update on coronary artery disease and chronic kidney disease. Int. J. Nephrol. 2014, 2014, 767424. [CrossRef] [PubMed]

66. Budoff, M.J.; Achenbach, S.; Blumenthal, R.S.; Carr, J.J.; Goldin, J.G.; Greenland, P.; Guerci, A.D.; Lima, J.A.C.; Rader, D.J.; Rubin, G.D.; et al. Assessment of coronary artery disease by cardiac computed tomography: A scientific statement from the American Heart Association Committee on Cardiovascular Imaging and Intervention, Council on Cardiovascular Radiology and Intervention, and Committee on Cardiac Imaging, Council on Clinical Cardiology. Circulation 2006, 114, 1761-1791. [CrossRef] [PubMed]

67. Bover, J.; Evenepoel, P.; Ureña-Torres, P.; Vervloet, M.G.; Brandenburg, V.; Mazzaferro, S.; Covic, A.; Goldsmith, D.; Massy, Z.A. Pro: Cardiovascular calcifications are clinically relevant. Nephrol. Dial. Transplant. 2015, 30, 345-351. [CrossRef] [PubMed] 
68. Mazzaferro, S.; Tartaglione, L.; Rotondi, S.; Bover, J.; Goldsmith, D.; Pasquali, M. News on BiomarkersinCKD-MBD. Semin. Nephrol. 2014, 34, 598-611. [CrossRef] [PubMed]

69. Russo, R.; Di Iorio, B.; Di Lullo, L.; Russo, D. Epicardial adipose tissue: New parameter for cardiovascular risk assessment in high risk populations. J. Nephrol. 2018, 31, 847-853. [CrossRef] [PubMed]

70. Di Lullo, L.; Floccari, F.; Santoboni, A.; Barbera, V.; Rivera, R.F.; Granata, A.; Morrone, L.; Russo, D. Progression of cardiac valve calcification and decline of renal function in CKD patients. J. Nephrol. 2013, 26, 739-744. [CrossRef] [PubMed]

71. Alexopoulos, N.; McLean, D.S.; Janik, M.; Arepalli, C.D.; Stillman, A.E.; Raggi, P. Epicardial adipose tissue and coronary artery plaque characteristics. Atherosclerosis 2010, 210, 150-154. [CrossRef] [PubMed]

72. Tsushima, H.; Kitagawa, T.; Urabe, Y.; Tatsugami, F.; Awai, K.; Kihara, Y. Association of epicardial and abdominal visceral adipose tissue with coronary atherosclerosis in patients with a coronary artery calcium score of zero. Circ. J. 2015, 79, 1084-1091. [CrossRef] [PubMed]

73. Nerlekar, N.; Brown, A.J.; Muthalaly, R.G.; Talman, A.; Hettige, T.; Cameron, J.D.; Wong, D.T. Association of epicardial adipose tissue and high-risk plaque characteristics: A systematic review and meta-analysis. J. Am. Heart Assoc. 2017, 6, e006379. [CrossRef] [PubMed]

74. Picard, F.A.; Gueret, P.; Laissy, J.P.; Champagne, S.; Leclercq, F.; Carrie, D.; Juliard, J.M.; Henry, P.; Niarra, R.; Chatellier, G.; et al. Epicardial Adipose Tissue Thickness Correlates with the Presence and Severity of Angiographic Coronary Artery Disease in Stable Patients with Chest Pain. PLoS ONE 2014, 9, e110005. [CrossRef] [PubMed]

75. Kim, B.J.; Kim, B.S.; Kang, J.H. Echocardiographic Epicardial Fat Thickness Is Associated With Coronary Artery Calcification-Results From the CAESAR Study. Circ. J. 2015, 79, 818-824. [CrossRef] [PubMed]

76. Sag, S.; Yildiz, A.; Gullulu, S.; Gungoren, F.; Ozdemir, B.; Cegilli, E.; Oruc, A.; Ersoy, A.; Gullulu, M. Early atherosclerosis in normotensive patients with autosomal dominant polycystic kidney disease: The relation between epicardial adipose tissue thickness and carotid intima-media thickness. SpringerPlus 2016, 5, 211. [CrossRef] [PubMed]

77. Kerr, J.D.; Holden, R.M.; Morton, A.R.; Nolan, R.L.; Hopman, W.M.; Pruss, C.M.; Garland, J.S. Associations of epicardial fat with coronary calcification, insulin resistance, inflammation, and fibroblast growth factor-23 in stage 3-5 chronic kidney disease. BMC Nephrol. 2013, 14, 26. [CrossRef] [PubMed]

78. Zuo, H.; Zhang, Y.; Ma, Q. Correlation between coronary atherosclerosis calcification and epicardial adipose tissue volume in patients with nephropathy. Exp. Ther. Med. 2018, 16, 4669-4673. [CrossRef] [PubMed]

79. Tonbul, H.Z.; Turkmen, K.; Kayıkcıoglu, H.; Ozbek, O.; Kayrak, M.; Biyik, Z. Epicardial adipose tissue and coronary artery calcification in diabetic and nondiabetic end-stage renal disease patients. Ren. Fail. 2011, 33, 770-775. [CrossRef] [PubMed]

80. Turan, M.N.; Gungor, O.; Asci, G.; Kircelli, F.; Acar, T.; Yaprak, M.; Ceylan, M.; Demirci, M.S.; Bayraktaroglu, S.; Toz, H.; et al. Epicardial adipose tissue volume and cardiovascular disease in hemodialysis patients. Atherosclerosis 2013, 226, 129-133. [CrossRef] [PubMed]

81. Gauß, S.; Klinghammer, L.; Jahn, D.; Schuhbäck, A.; Achenbach, S.; Marwan, M. Epicardial fat and coronary artery calcification in patients on long-term hemodialysis. J. Comput. Assist. Tomogr. 2014, 38, 768-772. [CrossRef] [PubMed]

82. Cordeiro, A.C.; Amparo, F.C.; Oliveira, M.A.; Amodeo, C.; Smanio, P.; Pinto, I.M.; Lindholm, B.; Stenvinkel, P.; Carrero, J.J. Epicardial fat accumulation, cardiometabolic profile and cardiovascular events in patients with stages 3-5 chronic kidney disease. J. Intern. Med. 2015, 278, 77-87. [CrossRef] [PubMed]

83. Christensen, R.H.; Von Scholten, B.J.; Hansen, C.S.; Heywood, S.E.; Rosenmeier, J.B.; Andersen, U.B.; Hovind, P.; Reinhard, H.; Parving, H.H.; Pedersen, B.K.; et al. Epicardial, pericardial and total cardiac fat and cardiovascular disease in type 2 diabetic patients with elevated urinary albumin excretion rate. Eur. J. Prev. Cardiol. 2017, 24, 1517-1524. [CrossRef] [PubMed]

84. Ozkurt, S.; Karavelioğlu, Y.; Musmul, A. Echocardiographic evaluation of epicardial adipose tissue in non-diabetic, non-hypertensive hemodialysis patients. Ren. Fail. 2013, 35, 891-895. [CrossRef] [PubMed]

85. Gitsioudis, G.; Schmahl, C.; Missiou, A.; Voss, A.; Schüssler, A.; Abdel-Aty, H.; Buss, S.J.; Mueller, D.; Vembar, M.; Bryant, M.; et al. Epicardial adipose tissue is associated with plaque burden and composition and provides incremental value for the prediction of cardiac outcome. A clinical cardiac computed tomography angiography study. PLoS ONE 2016, 11, e0155120. [CrossRef] [PubMed] 
86. Reinhardt, M.; Cushman, T.R.; Thearle, M.S.; Krakoff, J. Epicardial adipose tissue is a predictor of decreased kidney function and coronary artery calcification in youth- and early adult onset type 2 diabetes mellitus. J. Endocrinol. Investig. 2019. [CrossRef]

87. Barros, X.; Dirrichs, T.; Koos, R.; Reinartz, S.; Kaesler, N.; Kramann, R.; Gladziwa, U.; Ketteler, M.; Floege, J.; Marx, N.; et al. Epicardial adipose tissue in long-term hemodialysis patients: Its association with vascular calcification and long-term development. J. Nephrol. 2016, 29, 241-250. [CrossRef] [PubMed]

88. D'Marco, L.G.; Bellasi, A.; Kim, S.; Chen, Z.; Block, G.A.; Raggi, P. Epicardial adipose tissue predicts mortality in incident hemodialysis patients: A substudy of the Renagel in New Dialysis trial. Nephrol. Dial. Transplant. 2013, 28, 2586-2595. [CrossRef] [PubMed]

89. Ko, S.M.; Zhang, C.; Chen, Z.; D’Marco, L.; Bellasi, A.; Stillman, A.E.; Block, G.; Raggi, P. Epicardial adipose tissue volume increase in hemodialysis patients treated with sevelamer or calcium-based phosphate binders: A substudy of the Renagel in new dialysis trial. J. Nephrol. 2016, 29, 683-690. [CrossRef] [PubMed]

90. Liang, K.W.; Tsai, I.C.; Lee, W.J.; Lin, S.Y.; Lee, W.L.; Lee, I.T.; Fu, C.P.; Wang, J.S.; Sheu, W.H. Correlation between reduction of superior interventricular groove epicardial fat thickness and improvement of insulin resistance after weight loss in obese men. Diabetol. Metab. Syndr. 2014, 6, 115. [CrossRef] [PubMed]

91. Iacobellis, G.; Singh, N.; Wharton, S.; Sharma, A.M. Substantial changes in epicardial fat thickness after weight loss in severely obese subjects. Obesity 2008, 16, 1693-1697. [CrossRef] [PubMed]

92. Alexopoulos, N.; Melek, B.H.; Arepalli, C.D.; Hartlage, G.R.; Chen, Z.; Kim, S.; Stillman, A.E.; Raggi, P. Effect of intensive versus moderate lipid-lowering therapy on epicardial adipose tissue in hyperlipidemic post-menopausal women: A substudy of the BELLES trial (Beyond Endorsed Lipid Lowering with EBT Scanning). J. Am. Coll. Cardiol. 2013, 61, 1956-1961. [CrossRef] [PubMed]

93. Soucek, F.; Covassin, N.; Singh, P.; Ruzek, L.; Kara, T.; Suleiman, M.; Lerman, A.; Koestler, G.; Friedman, P.A.; Lopez-Jimenez, F.; et al. Effects of atorvastatin $(80 \mathrm{mg})$ therapy on quantity of epicardial adipose tissue in patients undergoing pulmonary vein isolation for atrial fibrillation. Am. J. Cardiol. 2015, 116, 1443-1446. [CrossRef] [PubMed]

94. Bouchi, R.; Terashima, M.; Sasahara, Y.; Asakawa, M.; Fukuda, T.; Takeuchi, T.; Nakano, Y.; Murakami, M.; Minami, I.; Izumiyama, H.; et al. Luseogliflozin reduces epicardial fat accumulation in patients with type 2 diabetes: A pilot study. Cardiovasc. Diabetol. 2017, 16, 32. [CrossRef] [PubMed]

95. Fukuda, T.; Bouchi, R.; Terashima, M.; Sasahara, Y.; Asakawa, M.; Takeuchi, T.; Nakano, Y.; Murakami, M.; Minami, I.; Izumiyama, H.; et al. Ipragliflozin reduces epicardial fat accumulation in non-obese type 2 diabetic patients with visceral obesity: A pilot study. Diabetes Ther. 2017, 8, 851-861. [CrossRef] [PubMed]

96. Sato, T.; Aizawa, Y.; Yuasa, S.; Kishi, S.; Fuse, K.; Fujita, S.; Ikeda, Y.; Kitazawa, H.; Takahashi, M.; Sato, M.; et al. The effect of dapagliflozin treatment on epicardial adipose tissue volume. Cardiovasc. Diabetol. 2018, 17, 6. [CrossRef] [PubMed]

97. Yagi, S.; Hirata, Y.; Ise, T.; Kusunose, K.; Yamada, H.; Fukuda, D.; Salim, H.M.; Maimaituxun, G.; Nishio, S.; Takagawa, Y.; et al. Canagliflozin reduces epicardial fat in patients with type 2 diabetes mellitus. Diabetol. Metab. Syndr. 2017, 9, 78. [CrossRef] [PubMed]

98. Dutour, A.; Abdesselam, I.; Ancel, P.; Kober, F.; Mrad, G.; Darmon, P.; Ronsin, O.; Pradel, V.; Lesavre, N.; Martin, J.C.; et al. Exenatide decreases liver fat content and epicardial adipose tissue in patients with obesity and type 2 diabetes: A prospective randomized clinical trial using magnetic resonance imaging and spectroscopy. Diabetes Obes. Metab. 2016, 18, 882-891. [CrossRef] [PubMed]

99. Iacobellis, G.; Mohseni, M.; Bianco, S.D.; Banga, P.K. Liraglutide causes large and rapid epicardial fat reduction. Obesity 2017, 25, 311-316. [CrossRef] [PubMed]

100. Lima-Martínez, M.M.; Paoli, M.; Rodney, M.; Balladares, N.; Contreras, M.; D’Marco, L.; Iacobellis, G. Effect of sitagliptin on epicardial fat thickness in subjects with type 2 diabetes and obesity: A pilot study. Endocrine 2016, 51, 448-455. [CrossRef] [PubMed]

101. Parisi, V.; Petraglia, L.; D’Esposito, V.; Cabaro, S.; Rengo, G.; Caruso, A.; Grimaldi, M.G.; Baldascino, F.; De Bellis, A.; Vitale, D.; et al. Statin therapy modulates thickness and inflammatory profile of human epicardial adipose tissue. Int. J. Cardiol. 2019, 274, 326-330. [CrossRef] [PubMed]

102. Díaz-Rodríguez, E.; Agra, R.M.; Fernández, Á.L.; Adrio, B.; García-Caballero, T.; González-Juanatey, J.R.; Eiras, S. Effects of dapagliflozin on human epicardial adipose tissue: Modulation of insulin resistance, inflammatory chemokine production, and differentiation ability. Cardiovasc. Res. 2018, 114, 336-346. [CrossRef] [PubMed] 
103. Sacks, H.S.; Fain, J.N.; Cheema, P.; Bahouth, S.W.; Garrett, E.; Wolf, R.Y.; Wolford, D.; Samaha, J. Inflammatory genes in epicardial fat contiguous with coronary atherosclerosis in the metabolic syndrome and type 2 diabetes: Changes associated with pioglitazone. Diabetes Care 2011, 34, 730-733. [CrossRef] [PubMed]

104. Grosso, A.F.; de Oliveira, S.F.; de Lourdes Higuchi, M.; Favarato, D.; de Oliveira Dallan, L.A.; da Luz, P.L. Synergistic anti-inflammatory effect: Simvastatin and pioglitazone reduce inflammatory markers of plasma and epicardial adipose tissue of coronary patients with metabolic syndrome. Diabetol. Metab. Syndr. 2014, 6, 47. [CrossRef] [PubMed]

105. Kidney Disease: Improving Global Outcomes (KDIGO) Lipid Work Group. KDIGO Clinical Practice Guideline for Lipid Management in Chronic Kidney Disease. Kidney Int. 2013, 3, 259-305.

106. American Diabetes Association. Standards of Medical Care in Diabetes 2018. Diabetes Care 2018, 41, S13-S27. [CrossRef] [PubMed]

107. National Kidney Foundation. KDOQI Clinical Practice Guideline for Diabetes and CKD. Am. J. Kidney Dis. 2012, 60, 850-886. [CrossRef] [PubMed]

108. Gaborit, B.; Jacquier, A.; Kober, F.; Abdesselam, I.; Cuisset, T.; Boullu-Ciocca, S.; Emungania, O.; Alessi, M.C.; Clément, K.P.; Bernard, M.; et al. Effects of bariatric surgery on cardiac ectopic fat: Lesser decrease in epicardial fat compared to visceral fat loss and no change in myocardial triglyceride content. J. Am. Coll. Cardiol. 2012, 60, 1381-1389. [CrossRef] [PubMed]

109. Smail, H.; Baciu, A.; Dacher, J.N.; Litzler, P.Y. Surgical resection of circumferential epicardial adipose tissue hypertrophy: Case report and systematic review of the literature. J. Thorac. Cardiovasc. Surg. 2016, 151, e27-e30. [CrossRef] [PubMed]

110. Hakeem, A.; Bhatti, S.; Chang, S.M. Screening and risk stratification of coronary artery disease in end-stage renal disease. JACC Cardiovasc. Imaging 2014, 7, 715-728. [CrossRef] [PubMed]

(C) 2019 by the authors. Licensee MDPI, Basel, Switzerland. This article is an open access article distributed under the terms and conditions of the Creative Commons Attribution (CC BY) license (http:/ / creativecommons.org/licenses/by/4.0/). 